\title{
Training on Heat Detection to Increase the Success Rate of Cattle Artificial Insemination for Girinka Beneficiaries in Huye District, Rwanda
}

\author{
Nancy Sibo ${ }^{1,3}$, Sylvia Callender ${ }^{2}$, Jenae Logan ${ }^{3}$, Phaedra Henley ${ }^{3} \&$ Rex Wong ${ }^{3}$ \\ ${ }^{1}$ Integrated Regional Technical College, Rwanda \\ ${ }^{2}$ Partners in Health, Rwanda \\ ${ }^{3}$ University of Global Health Equity, Rwanda \\ Correspondence: Nancy Sibo, Integrated Regional Technical College, Rwanda.
}

Received: January 12, 2019

doi:10.5430/jms.v10n2p42
Accepted: March 7, 2019

Online Published: March 11, 2019

URL: https://doi.org/10.5430/jms.v10n2p42

\begin{abstract}
Cattle farming is important for the socio-economic development of Rwanda, representing $12 \%$ of the national gross domestic product (GDP). In general, livestock production is a primary source of income. Recognizing the importance of cattle, the Government of Rwanda introduced the Girinka program in 2006 to reduce poverty and childhood malnutrition by providing poor people with dairy cows. The sustainability of the Girinka program relies on the successful breeding of cattle. Artificial Insemination (AI) is a method that can enhance cattle reproduction, but many Girinka beneficiaries did not have the requisite knowledge to maximize the success rate of AI by tracking the estrus cycle (heat detection) of their cattle.

This project aimed to study the effect of training Girinka farmers on heat detection using the International Livestock Research Institute (ILRI) materials on cattle AI. A two-day training was provided to 74 Girinka cattle farmers. The cattle AI success rate and the farmers' knowledge of heat detection were measured.

The overall knowledge of farmers on cattle estrus cycle significantly increased from $37.16 \%$ pre-intervention to 92.34\% post-intervention $(\mathrm{P}=0.008)$. The AI success rate significantly increased from $44 \%$ pre-intervention to $58.7 \%$ post-intervention $(\mathrm{P}<0.001)$.

The study showed that by providing an evidence-based training to farmers on heat detection and estrus cycle in cattle could increase the success rate of AI. The same training is recommended for all Girinka beneficiaries in Rwanda. Longer term follow-up and scaling-up of the project should be considered to maximize the benefits.
\end{abstract}

Keywords: artificial insemination, estrus, cattle, heat detection

\section{Introduction}

Cattle farming is important for the socio-economic development of Rwanda. In addition to contributing $12 \%$ to national gross domestic product (GDP), livestock production also plays a critical role in the well-being of the population (Kayigema, 2014; Rwanda Food Security, 2011). Livestock production is the main source of income for the 39\% people living below the poverty line in Rwanda (Rwanda Food Security, 2011; NISR, 2015). Milk and meat products from livestock are an important source of dietary protein for the $44 \%$ of children who suffer from stunting (Rwanda Food Security, 2011).

Recognizing the importance of cattle farming, the Government of Rwanda introduced the Girinka program in 2006 to reduce poverty and childhood malnutrition in rural areas by providing poor people with dairy cows (Mudingu, 2017). As of 2017, more than 259,087 households had received cows from Girinka (Kayigema, 2014; Mudingu, 2017). These dairy cows have contributed to an increase in milk production that has helped to reduce malnutrition and increase income (Mudingu, 2017). However, the sustainability of the program relies on the successful breeding of cattle, which is in turn dependent on a farmer's ability to recognize when his/her animals are in heat.

Artificial Insemination (AI) is a preferred method of enhancing cattle reproduction, as it contributes to the reduction of sexual transmissible diseases and of recessive genes (Noguera et al., 2013). AI was arguably the first great 
biotechnology innovation related to animal reproduction and breeding, dating back to 1780s; and the technology has grown significantly in the 1940s (Malik et al., 2012; Foote, 1999; Gordon, 2004). By placing sperm from genetically superior bulls into uterus of cattle (Foote, 1992; Morrell, 2011; Foote, 2002; Dalton, 2011), the bovine AI procedure has better breeding efficiency and has brought enormous economic benefits to the livestock farming industry - from reducing sexual transmissible diseases to improving milk production (Noguera et al., 2013; Das et al., 2016; Stevenson, 1997; Rodriguez, 2012). It was first introduced to Rwanda in the 1990s (NISR, 2013), but services were interrupted during the 1994 Genocide and only resumed in 2001 when the country renovated its agriculture framework (Chatikobo, 2009). Now, whenever farmers notice signs of heat in cows could call the inseminator and pay 2000-3000 RWF insemination fees.

Most developed countries generally have AI success rates over 80\% (Magyar, 1991), higher than the Food and Agriculture Organization (FAO) recommendation of 75\% (FAO, 2008). The AI success rates in low income countries including Bangladesh and Ethiopia, however, were only around 50\% (Shamsuddin et al., 2001; Uddin et al., 2014; Haque, Gofur, Asaduzzama, \& Bhuiyan, 2015 ; Ashebir, 2016). In Rwanda, the success rate was around $44 \%$ in 2018 (MINAGRI, 2013).

Many barriers to the success of AI have been identified, including the physical, biological and nutritional conditions of the cow, the cattle rearing system, and the handling of semen by as well as the general skill of the inseminators (Shamsuddin et al.,2001; Uddin et al., 2010; Samre et al., 2015; RAB, 2015, Nishimwe et al., 2015; Gebre et al., 2007; Joost et.al, 2010; Parish, 2010); RAB, 2013; Perry et al., 2011). In addition to these barriers, another challenge is to accurately detect the estrus signs (also known as the "heat"). Heat is the period when cows can conceive and thus is the only time for successful AI (Nebel, 2014). This is critically important since the estrus cycle of cows happens only once a month (John, 2009; Heres et al.,2000; Nishimwe et al., 2015; Chandel \& Pushpa, 2014).

Since frozen-thawed sperm can only survive approximately 20 to 24 hours in the female reproductive tract and the heat only lasts for 48 hours, timing of AI is critical to ensure the fertile life of sperm and egg overlap (Boujenane \& Boussaq, 2014; Foote, 2002; Colazo \& Mapletoft, 2014). A study conducted in Tunisia showed that by improving farmer's knowledge on heat detection, the success rate of AI increased by 15\% (Salem \& Khemiri, 2008; Nebel, 2014). In Rwanda's, farmer's knowledge of detecting heat and its effect on AI success rate has not previously been studied. Accordingly, this project aimed to study the effect that training Girinka farmers on heat detection has on farmers' knowledge and cattle AI success rate. By improving cattle farmers' ability to detect heat and in turn increasing the success rate of AI, this project may improve the socio-economic statuses of livestock farmers in Rwanda.

\section{Method}

\subsection{Setting}

This study was conducted in Huye district of Rwanda. About $20 \%$ of all the cattle in this district were provided by the Girinka program (RAB, 2013) and about 67\% of cattle farms utilized AI in 2014 and 2015, with an overall AI success rate of $44 \%$ (Makuza, et al, 2016). There are two main inseminator centers in the district.

\subsection{Study Design and Sample}

The project utilized a pre- and post-intervention study design to investigate the effect of training farmers to detect heat in cattle on the success rate of AI in the district. The farmers' knowledge of concepts related to heat detection was assessed before and after a two-day training in November 2017. All farmers who received a cow from Girinka program or have a first generation offspring of a Girinika cow, and who participate in AI in the Huye area were invited to participate in the training session. The AI success rate among the cows owned by the farmers was collected from the Huye district veterinary office three weeks before and two months after the intervention.

\subsection{Intervention}

Two inseminators who were veterinary technicians conducted the training. The training included information on heat period, cattle estrus signs, detection techniques, and timing. The training materials were adapted from International Livestock Research Institute (ILRI) materials developed for smallholder dairy farmers (ILRI, 2016) and from Heat Detection Strategies for Dairy Cattle (Graves, 2012). The training was conducted in Kinyarwanda, the local language in Rwanda.

\subsection{Measures and Data Collection}

Two key measures included the farmer's knowledge score and the AI success rate. The knowledge score was obtained by having the participants complete a written test, which included six multiple choice questions. The test 
was developed based on the materials by ILRI. The six questions were: 1) Define the estrus cycle of cows, 2) What does "heat" mean in cows? 3) How long is the estrus cycle of cows? 4) What is the appropriate time to check for heat period? 5) What are the signs of cows in estrus? and 6) What are the methods of estrus detection used at farm level? The test was completed immediately before and after the training session. Informed consent was obtained from all participants. The AI success rates were obtained through the District Veterinary Office in Huye, who keep records on each famer. The University Global Health Equity institutional review board provided ethical approval for the study.

\subsection{Data Analysis}

A chi-square test was used to compare the pre- and post-intervention AI success rates, and the Wilcoxon signed rank test was used to compare the pre- and post-intervention knowledge scores (overall and by each question) to adjust for non-normal distribution of data. All statistics were analyzed using STATA v.13, with the significance level set at 0.05 .

\section{Results}

Among the 74 farmers from Huye district who participated in the training, $70.5 \%$ received their cows directly from the Girinka program and $29.5 \%$ received a cow from the first generation produced by the cows given from Girinka. Forty-seven (63.5\%) females and $27(36.5 \%)$ males participated in the training, with ages ranging from 30 to 80 years (Table 1). Most of the participants (52.7\%) were in the age range of 41-50 years.

Table 1. Table summarizing the participants' characteristics

\begin{tabular}{llc}
\hline Sample & & 74 \\
\hline Sex & Female & $47(63.5 \%)$ \\
\hline & Male & $27(36.5 \%)$ \\
\hline Age groups (year) & $20-40$ & $3(4 \%)$ \\
\hline & $41-60$ & $65(87.9 \%)$ \\
\hline & $61-80$ & $6(8.2 \%)$ \\
\hline
\end{tabular}

The participating farmers owned a total of 131 cows. The AI success rate significantly increased from $44 \%$ pre-intervention to $58.7 \%$ post-intervention, with $\mathrm{P}<0.001$ (Table 2). The overall average knowledge score of the farmers significantly increased from $37.16 \%$ pre-intervention to $92.34 \%$ post-intervention, with $\mathrm{P}=0.008$ (Table 2 ). For all six questions about the knowledge, there were statistically significant increases in the percentage of farmers answering correctly, with question 1 related to the knowledge of estrus cycle having the biggest increase from $31.1 \%$ pre-intervention to $95.9 \%$ post intervention, a $64.8 \%$ improvement $(\mathrm{P}<0.001, \mathrm{CI}=0.53,0.77)$. The smallest increase in score was question 2 related to knowledge on heat period of cows, which increased from $55.4 \%$ pre-intervention to $98.6 \%$ post-intervention, a $43.2 \%$ improvement $(\mathrm{P}<0.001$ and $\mathrm{CI}=0.31,0.55)$ (Table 2$)$.

Table 2. Table summarizing the pre-and post-intervention results

\begin{tabular}{|c|c|c|c|c|}
\hline & Pre-intervention & Post-intervention & Change & P-value $(95 \% \mathrm{CI})$ \\
\hline \multicolumn{5}{|l|}{ Cattle's AI success rate } \\
\hline Sample (number of cows) & 131 & 131 & - & - \\
\hline Cattle AI success rate & $44.2 \%$ & $58.7 \%$ & $14.5 \%$ & $\begin{array}{l}<0.001 \\
(12.20,16.77)\end{array}$ \\
\hline \multicolumn{5}{|l|}{ Farmer's knowledge } \\
\hline Sample (number of farmers) & 74 & 74 & & - \\
\hline Overall knowledge score (mean \pm SD) & $37.1 \% \pm 13.9 \%$ & $92.3 \% \pm 11.7 \%$ & $55.2 \%$ & $\begin{array}{l}<0.008 \\
(0.50,0.61)\end{array}$ \\
\hline $\begin{array}{lllll}\text { Question } & \text { 1: } & \text { Estrus } & \text { cycle } & \text { general }\end{array}$ & $31.1 \% \pm 46.6 \%$ & $95.9 \% \pm 19.9 \%$ & $64.8 \%$ & $<0.001$ \\
\hline
\end{tabular}




\begin{tabular}{|c|c|c|c|c|}
\hline information & & & & $(0.53,0.77)$ \\
\hline Question 2: Heat period of cows & $55.4 \% \pm 50.0 \%$ & $98.6 \% \pm 11.6 \%$ & $43.2 \%$ & $\begin{array}{l}<0.001 \\
(0.31,0.55)\end{array}$ \\
\hline Question 3: Cattle estrus duration & $41.9 \% \pm 49.7 \%$ & $97.3 \% \pm 16.3 \%$ & $55.4 \%$ & $\begin{array}{l}<0.001 \\
(0.43,0.68)\end{array}$ \\
\hline Question 4: Time to check for heat period & $40.5 \% \pm 49.4 \%$ & $93.2 \% \pm 25.3 \%$ & $52.7 \%$ & $\begin{array}{l}<0.001 \\
(0.39,0.66)\end{array}$ \\
\hline $\begin{array}{l}\text { Question 5: Manifestations of cows in } \\
\text { estrus }\end{array}$ & $33.8 \% \pm 47.6 \%$ & $86.5 \% \pm 34.4 \%$ & $52.7 \%$ & $\begin{array}{l}<0.001 \\
(0.36,0.69)\end{array}$ \\
\hline Question 6: Cattle estrus signs & $20.3 \% \pm 40.5 \%$ & $82.4 \% \pm 38.3 \%$ & $62.1 \%$ & $\begin{array}{l}<0.001 \\
(0.49,0.75)\end{array}$ \\
\hline
\end{tabular}

\section{Discussion}

The results of our study suggest that the training provided to the farmers increased their level of knowledge on the estrus cycle of cows. The training was also associated with an increase in AI success rate; which is consistent with some other previously published studies which found that similar training on cattle heat detection can improve AI success rates (Goncu et al., 2017; Sakatani et al., 2016; Woldu et al., 2011; Mpofu, 2002). The 14.5\% increase in AI success rate observed in this study is also consistent with the results of some other similar studies conducted in Ethiopia, Malawi or China, although their increase in AI success rates was as much as 22\% (Woldu et al., 2011; Mpofu, 2002; Yin, et al., 2013).

Since the duration of heat in cows is only 48 hours and the estrus cycle only occurs every 21 days (Selvam \& Archunan, 2017; Johnson, 2016), knowing the signs of heat and the physical and behavioral manifestations of cows is critical to successful insemination (Hansen, 2013). Since AI services are not free, not being able to inseminate successfully can result in paying for inseminators more than once, thus posing a financial loss to farmers. Our training empowered the farmers with knowledge to understand the signs of the heat period and therefore to make sure that $\mathrm{AI}$ is requested at the right time, increasing the likelihood of successful insemination.

Our study used a strategic problem solving (SPS) approach (Banaszak-Holl et al., 2011) to address the cow insemination issue. SPS is an 8-step process applied to understand and address a problem. By following the SPS process, we created a problem statement that allowed us to focus on a single issue for the project. Issues surrounding artificial insemination can be complex and convoluted. By clearly defining the problem, the effort and resources invested to this project became more focused. Our objective was clearly set from the beginning and that provided to the team and created a shared direction. We conducted extensive literature review to understand the general causes of issues leading to the problem then applied such general knowledge and applied it to our project. Our knowledge test questions were designed based on an evidence-based curriculum; the questions provided us with baseline information on the farmers' knowledge and the specific areas that they needed further training on. With such information, we developed a training program that specifically targeted the root cause of the problem.

Our training program was designed based on a thorough literature review and methodology recommended by the ILRI; the components of the training specifically targeted the most important factors in successful AI. The development of curriculum and training materials had also taken the local culture and audience's comprehension into consideration. The training was delivered using simple terminology in the local language (Kinyarwanda) to ensure that all farmers could understand. Visual aids including graphs, pictures, and videos were used to enhance farmers' understanding. The individuals selected to deliver the trainings were veterinary technicians and experienced inseminators.

By following the SPS process and implementing an evidence-based, data-driven intervention, our training was associated with improvements in AI insemination rate. However, there were a number of limitations in the project. Firstly, we could not attribute the increase in AI success rate solely to our intervention, as the success of artificial insemination depends on farmers' knowledge on the heat detection and estrus cycle management (52\%), semen source, semen handling and insemination techniques (24\%), and skills and availability of the inseminator (18\%) (Nishimwe, et al., 2015). Secondly, since the post-intervention assessment on knowledge was conducted 
immediately after the training session, a short-term increase in knowledge scores was highly likely, while the long-term retention of knowledge has yet to be determined.

\section{Conclusion}

This project utilized a pre- and post-intervention study design to assess the effect of providing evidence-based training on estrus cycle to farmers on the success rate of AI. The intervention was associated with a significant increase in farmers' overall knowledge score from $37.16 \%$ to $92.34 \%$, and with an increase in the AI success rate from $44.22 \%$ to $58.7 \%$. The results indicated that by building farmers' knowledge, they can detect estrus cycle accurately, and in turn, maximize the AI success rate. If AI is performed at the optimal time, the unnecessary repetition of insemination can be decreased and calving intervals can be shortened. In Rwanda, where cattle farming is an important part of the economy and has significant impacts on the financial and physical wellness of farmers and their families, maximizing AI success has long term benefits at multiple levels. This education program was simple and effective and could be replicated in other regions where AI is performed. Longer term follow-up of the project should be considered to evaluate if intermittent refresher courses will be necessary to sustain the observed improvements.

\section{References}

Ashebir, G. (2016). Status of Artificial Insemination in Tigray Regional State, "Constraints and Acceptability under Field Condition". Journal of Dairy, Veterinary \& Animal Research, 3(3).

Banaszak-Holl, J., Nembhard, I. M. E., Taylor, L., \& Bradley, E. H. (2011). Leadership and management: a framework for action. Shortell and Kaluzny's Healthcare Management: Organizational Theory and Behavior, pp. 40-45.

Boujenane, I., \& Boussaq, K. (2014). Breed effects on semen traits of dairy and beef artificial insemination bulls. Livestock Research for Rural Development, 26(6).

Chandel, B., \& Pushpa. (2014). Effectiveness of Artificial Insemination in Dairy Cattles: Recent Evidences from India's Milking State of Gujarat. Indian Res. J. Ext. Edu, 14(4). Retrieved from http://www.seea.org.in/vol14-4-2014/05.pdf

Chatikobo, P. (2009). Artificial Insemination in Rwanda: Exploring Opportunities, Overcoming Challenges. Retrieved from https://cgspace.cgiar.org/bitstream/handle/10568/2444/Dairy News Vol 3.pdf?sequence=1

Colazo, M. G., \& Mapletoft, R. J. (2014). A review of current timed-AI (TAI) programs for beef and dairy cattle. Canadian Veterinary Journal, 55(8), 772-780. https://doi.org/10.1103/PhysRevLett.99.173603

Dalton, J. C. (2011). Strategies for Success in Heat Detection and Artificial Insemination What Causes Dairy Cattle to Show Signs of Heat?. Western Canadian Dairy Seminar, 23, 215-229. Retrieved from http://www.wcds.ca/proc/2011/Manuscripts/Dalton.pdf

Das, R., Sailo, L., Verma, N., Bharti, P., Saikia, J., Imtiwati, \& Kumar, R. (2016). Impact of heat stress on health and performance of dairy animals: A review. Veterinary World.

FAO-Food and Agriculture Organization. (2008). Small-scale dairy farming manual-Artificial Insemination (A.I) in Dairy Cattle and Buffalo (Vol. 4). Retrieved from ftp://ftp.fao.org/docrep/fao/011/t1265e/t1280e.pdf

Gebre Medhin, D., Bekana, M., Tegegne, A., \& Belihu, K. (2007). Status of Artificial Insemination Service in Ethiopia. Climate Change, Livestock and People: Challenges, Opportunities, and the Way Forward (pp. 87-103). Proceedings of the 17th Annual Conference of the Ethiopian Society of Animal Production (ESAP). Retrieved from http://cgspace.cgiar.org/bitstream/handle/10568/27942/ESAP_Proceedings_17.pdf?sequence=1

Goncu, S., Anitas, O., Gungor, C., \& Gokce, G. (2017). New Technology Usage for Sustainable Dairy Cow Reproductive Performances. Journal of Environmental Science and Engineering B, 6, 370-379.

Gordon, I. (2004). Reproductive Technologies in Farm Animal. Trowbridge: CABI Publishing. https://doi.org/10.1079/9780851998626.0000

Graves, M. W. (2012). Heat Detection Strategies for Dairy Cattle. University of Georgia. Retrieved from http://www.caes.uga.edu/Publications/displayHTML.cfm?pk_id=6304

Hansen, P. J. (2013). Antecedents of mammalian fertility: Lessons from the heat-stressed cow regarding the importance of oocyte competence for fertilization and embryonic development. Animal Frontiers, 3(4), 34-39. https://doi.org/10.2527/af.2013-0031 
Haque, M. N., Gofur, M. R., Asaduzzama, K. M., \& Bhuiyan, M. M. U. (2015). Factors Limiting the Pregnancy Rates in Artificially Inseminated Cows in Bangladesh. International Journal of Dairy Science, 10(6), 278-287. https://doi.org/10.3923/ijds.2015.278.287

ILRI. (2016). Smallholder dairy farmer training manual. Retrieved from https://cgspace.cgiar.org/rest/bitstreams/82258/retrieve

John, H. (2009). Estrus Synchronization for Heifers VCE Publications Virginia Tech. Retrieved December 19, 2017, from http://pubs.ext.vt.edu/400/400-302/400-302.html

Joost, S., Yvett, H., Haas, D., Mäki-Tanila, A., \& Gandini, G. (2010). Local cattle breeds in Europe, pp.26-99. Wageningen Academic Publishers. Re http://www.regionalcattlebreeds.eu/publications/documents/9789086866977cattlebreeds.pdf

Magyar, L. (1991). History of artificial insemination. Therapia Hungarica, 39(3), 151-153. Retrieved from http://www.ncbi.nlm.nih.gov/pubmed/17543840\%5Cnhttp://www.ncbi.nlm.nih.gov/pubmed/1818431

Makuza, R., Ntawubizi, M., \& Kabera, F. (2016). Adoption of Artificial Insemination Services in Dairy Cattle in Rwanda; Case Study of Kigali City. Journal of Animal Science Advances, 6(7), 1685. https://doi.org/10.5455/jasa.20160916044139

Malik, A., Wahid, H., Rosnina, Y., Kasim, A., \& Sabri, M. (2012). Effects of timed artificial insemination following estrus synchronization in postpartum beef cattle. Open Veterinary Journal, 2(1), 1-5. Retrieved from http://www.ncbi.nlm.nih.gov/pubmed/26623282

MINAGRI. (2013). National Dairy Strategy. Ministry of Agriculture and Animal Resources of Rwanda. Retrieved from http://www.minagri.gov.rw/fileadmin/user_upload/documents/STRAT.PLC/2013_National_Dairy_Stratey.pdf

Morrell, J. M. (2011). Artificial Insemination: Current and Future Trends, Artificial Insemination in Farm Animals (Dr. Milad Manafi $\quad$ Ed.). $\quad$ Retrieved from http://www.intechopen.com/books/artificial-insemination-in-farm-animals/artificial-insemination-current-and-f uture-trends

Mpofu, N. (2002). The Importance of Breeding Infrastructure and Support Services: The Success/Failure of Artificial Insemination as a Method of Disseminating Genetic Material to Smallholder Dairy Farmers in Southern Africa, pp. 1-6. AGTR Case Study. ILRI, Nairobi, Kenya. Retrieved from http://hdl.handle.net/10568/3526

Mudingu, J. (2017). Girinka Programme transforms livelihoods, reconciles communities, pp. 1-4. Retrieved from http://www.minagri.gov.rw/fileadmin/user_upload/SUCCESS_STORY/article_about_Girinka.pdf

Nebel, R. (2014). Timing of insemination depends on method of heat detection - Progressive Dairyman. Retrieved August 27, 2017, from http://www.progressivedairy.com/topics/a-i-breeding/timing-of-insemination-depends-on-method-of-heat-detect ion

Nishimwe, K. J. B., Manishimwe, R., Ayabagabo, J., Byukusenge, M., Habimana, R., \& Bareeba, F. (2015). Factors Affecting the Pregnancy Rate in Small Scale Dairy Farms After the Artificial Insemination in Rural Area, Rwanda. International Journal of Livestock Research ONLINE, 5(3). https://doi.org/10.5455/ijlr.20150316053842

NISR. (2013). National Institute of Statistics of Rwanda: Thematic Report on Agriculture. Pan African Medical Journal, 15(2), 4.

NISR. (2015). National Institute of Statistics of Rwanda: Poverty Profile Report Results - Integrated Household Living Conditions Survey [EICV].

Noguera, S., Vale, W. G., Ribeiro, H. F. L., Rolim Filho, S. T., Reis, A. N., Sousa, J. S., \& Silva, A. O. A. (2013). Fixed-time artificial insemination in cows and buffaloes using an intravaginal releasing progesterone insert. Livestock Research for Rural Development, 25(10).

Parish, J. A. (2010). The Estrous Cycle of Cattle. Extension Service of Mississippi State University, Cooperating with U.S. Department of Agriculture. Published in Furtherance of Acts of Congress. Retrieved from http://extension.msstate.edu/sites/default/files/publications/publications/p2616.pdf

Perry, A. G., Dalton, J. C., \& Geary, W. T. (2011). Management Factors Influencing Fertility in Beef Cattle 
Breeding Programs, pp. 165-192. Livestock and Range Research Laboratory. South Dakota State University, Brookings, SD.

RAB. (2013). Rwanda Agriculture Board: Annual report 2012-2013. Retrieved from http://rab.gov.rw/fileadmin/user_upload/Publications/Reports/Annual_Report/RAB-Annual_report_2012_20 13.pdf

Sakatani, M., Takahashi, M., \& Takenouchi, N. (2016). The efficiency of vaginal temperature measurement for detection of estrus in Japanese Black cows. The Journal of Reproduction and Development, 62(2), 201. https://doi.org/10.1262/JRD.2015-095

Salem, M. B., \& Khemiri, H. (2008). The impact of agricultural projects on cows' productivity, farmers' revenue and rural development in Tunisia. Livestock Research for Rural Development, 20(5), 1-4. Retrieved from http://www.lrrd.org/lrrd20/5/sale20070.htm

Samre, M., Alemayhu, T., \& Weldegebriel, S. (2015). Major Constraints of Artificial Insemination in and Around Alamata District, Tigray, Ethiopia. African Journal of Basic \& Applied Sciences, 7(5), 287-290. https://doi.org/10.5829/idosi.ajbas.2015.7.5.96167

Selvam, R. M., \& Archunan, G. (2017). A combinatorial model for effective estrus detection in Murrah buffalo. Veterinary World, 10(2), 209-213. https://doi.org/10.14202/vetworld.2017.209-213

Shamsuddin, M., Bhuyan, M. M. U., Sikder, T. K., Sugulle, A. H., Chandra, P. K., \& Alam, M. G. S. (2001). Constraints limiting the efficiency of artificial insemination of cattle in Bangladesh. International Atomic Energy Agency, 1220, 9-27.

Stevenson, J. S. (1997). Techniques to Maximize Conception Rates. Dept. of Animal Sciences, Kansas State University. Retrieved from http://www.wcds.ca/proc/1997/ch12-97.htm

Uddin, M. M., Huylenbroeck, G. V., Hagedorn, K., Sultana, M. N., \& Peters, K. J. (2010). Institutional and organizational issues in livestock services delivery in Bangladesh. Quarterly Journal of International Agriculture, 49(2), 111-125. Retrieved from http://ageconsearch.umn.edu/bitstream/155544/2/2_Uddin.pdf

Uddin, M., Sultana, M. N., Huylenbroek, G. V., \& Peters, K. (2014). Artificial insemination services under different institutional framework in Bangladesh. Bang. J. Anim. Sci, 43(3), 166-174. Retrieved from https://www.researchgate.net/profile/Mn_Sultana/publication/276857873_Artificial_insemination_services_und er_different_institutional_framework_in_Bangladesh/links/557960ef08ae752158706858/Artificial-insemination -services-under-different-institutional-framework-in-Bangladesh.pdf

Woldu, T., Giorgis, Y. T., \& Haile, A. (2011). Factors affecting conception rate in artificially inseminated cattle under farmers' condition in Ethiopia. Journal of Cell and Animal Biology, 5(16), 334-338. https://doi.org/10.5897/JCAB11.067

Yin, L., Hong, T., \& Liu, C. (2013). Estrus detection in dairy cows from acceleration data using self-learning classification models. Journal of Computers (Finland), 8(10), 2590-2597. https://doi.org/10.4304/jcp.8.10.2590-2597 